\title{
Effectiveness of Titanium-Platelet-Rich Autograft: A Preliminary Report
}

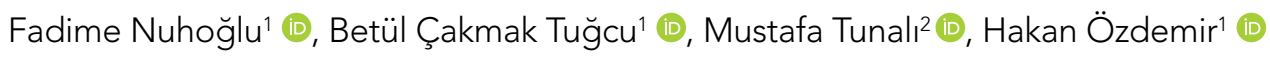 \\ ${ }^{1}$ Department of Ophthalmology, Bezmialem Vakıf University School of Medicine, İstanbul, Turkey \\ 2Department of Periodontology, Bezmialem Vakıf University School of Medicine, İstanbul, Turkey
}

Cite this article as: Nuhoğlu F, Çakmak Tuğcu B, Tunalı M, Özdemir H. Effectiveness of Titanium-Platelet-Rich Autograft: A Preliminary Report. JAREM 2018; 8(2): 91-5.

\begin{abstract}
Objective: The present study aimed to evaluate the effectiveness and reliability of titanium-platelet-rich fibrin (T-PRF) autograft implantation in patients who underwent this treatment method.

Methods: Our study included patients who underwent titanium-platelet-rich membrane autograft implantation at our clinic for the management of primary pterygium. Demographic characteristics of patients, size of the pterygium as determined during pre- and postoperative biomicroscopic examinations, presence of granulation tissue, recurrence, corneal, and other complications, condition of the implanted graft, and conjunctival epithelization were evaluated. The absence of recurrence was considered as a criterion of success.

Results: Twelve eyes belonging to total 12 patients (men, 5 and women, 7 ) with a mean age of $52.1 \pm 12.6$ (range, 30-75) years and mean followup period of $2.91 \pm 1.37$ (range, 1-5) months were included in the study. The follow-up period of total 8 cases exceeded 3 months. Recurrence was observed in $2(16.6 \%)$ cases.

Conclusion: Because no complications were oberved our study, this new surgical technique was considered reliable. Based on our preliminary reports, T-PRF autograft technique can be used as an alternative to other surgical techniques.
\end{abstract}

Keywords: Titanium-platelet-rich fibrin, autograft, pterygium

ORCID IDs of the authors: F.N. 0000-0002-4796-091X; B.Ç.T. 0000-0003-2858-6130; M.T. 0000-0002-1251-3431; H.Ö. 0000-0001-6426-3801.

\section{INTRODUCTION}

Pterygium is a degenerative, proliferative ocular surface disease characterized by fibrovascular extension of the conjunctiva over the cornea. It progresses slowly and courses with periods of inflammatory episodes and inactive periods. Clinically, the prevalence of pterygium ranged between $4 \%$ and $31 \%(1-4)$. The etiopathogenesis of pterygium has not been completely elucidated $(5,6)$.

The pathology of pterygium is characterized by conjunctivalization, chronic inflammation, cellular proliferation, remodeling of the connective tissue, and neovascularization. Several molecules, including fibroblast growth factor, platelet-derived growth factor (PDGF), transforming growth factor (TGF), tumor necrosis factor (TNF), cytokines, and matrix metalloproteinases, play roles in this active and invasive process $(7,8)$.

The main treatment for pterygium is surgery, and the basic objective is the prevention of recurrence. However, the most effective technique has not been precisely determined $(9,10)$. The oldest method used for pterygium surgery is the bare sclera technique. Implantation of conjunctival autograft, limbal conjunctival autograft, and amniotic membrane has been applied as surgical treatment. Combination treatments with chemotherapy, anti-vascular endothelial growth factor inhibitor (VEGFi), and radiotherapy have been integrated with these techniques to increase the success rates of surgical treatments (11).
Choukroun developed a platelet-rich fibrin (PRF) that contained intensive amounts of leukocytes and platelets (12). In this method, blood samples are placed in a glass tube and are centrifuged without adding any anticoagulant or cattle thrombin $(13,14)$. Some studies noted that blood prepared in a glass tube is activated with silica and that its fibrin content may have some side effects (15). Tunali et al. (16) eliminated the adverse effects of silica by preparing L-PRF with titanium (titanium-platelet-rich fibrin, TPRF). In histomorphometric analyses, it has been demonstrated that T-PRF has a tight fibrin network, and in vivo studies have displayed longer resorption times than Choukroun's autogenous fibrin. Ustaoğlu et al. (17) demonstrated the favorable effects of the T-PRF membrane on the healing of palatal mucosa wounds.

In a study performed by Can et al. (18) on rabbits, the favorable effects of PRF, which they had prepared in a glass tube on conjunctival healing had been demonstrated. The previous study suggested that this autograft can be used in the surgical treatment of pterygium. In our literature review, we could not find any study performed with T-PRF autograft in the treatment of pterygium surgery. Therefore, the present study aimed to determine the effectiveness and success of using T-PRF in the surgical treatment of pterygium.

\section{METHODS}

Bezmialem Vakıf University School of Medicine ethics committee approval and informed written consent of the patients were 


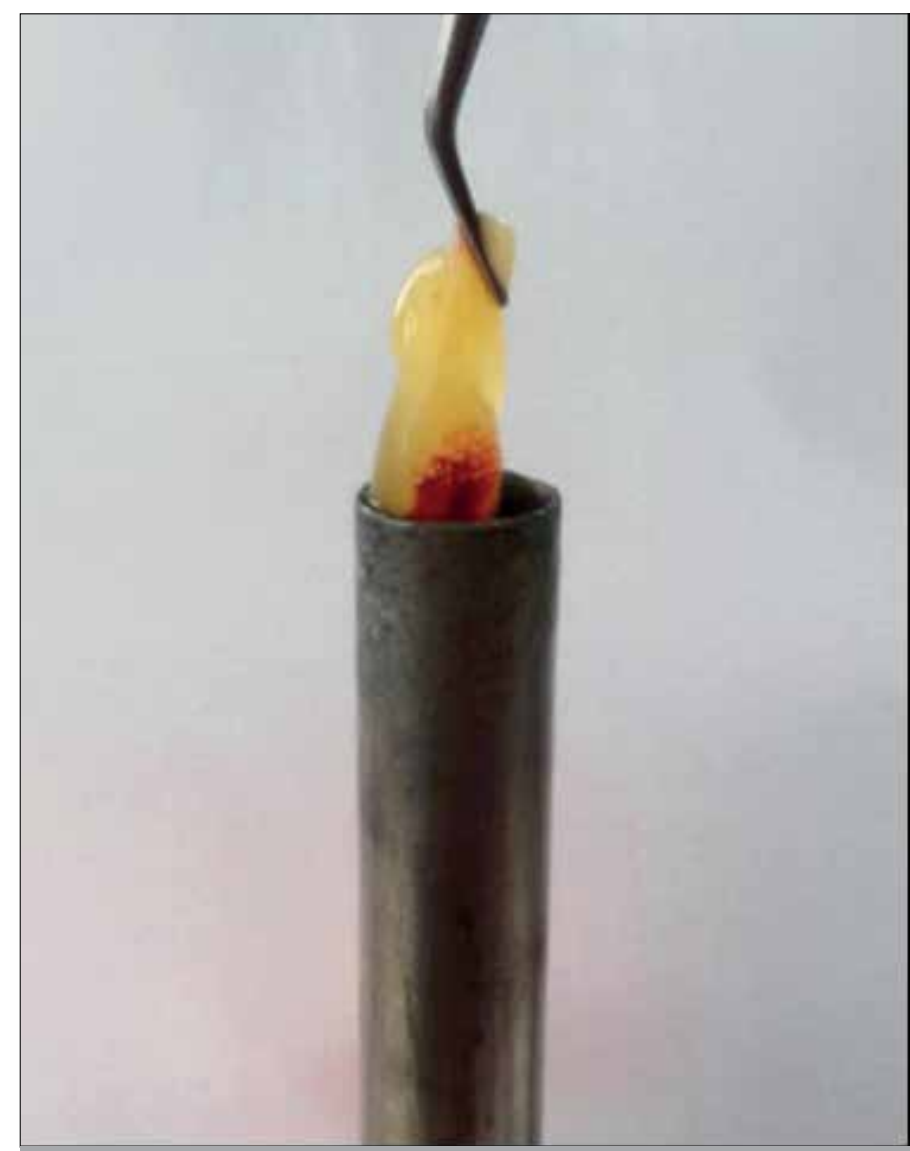

Figure 1. Preparation of titanium-platelet-rich fibrin

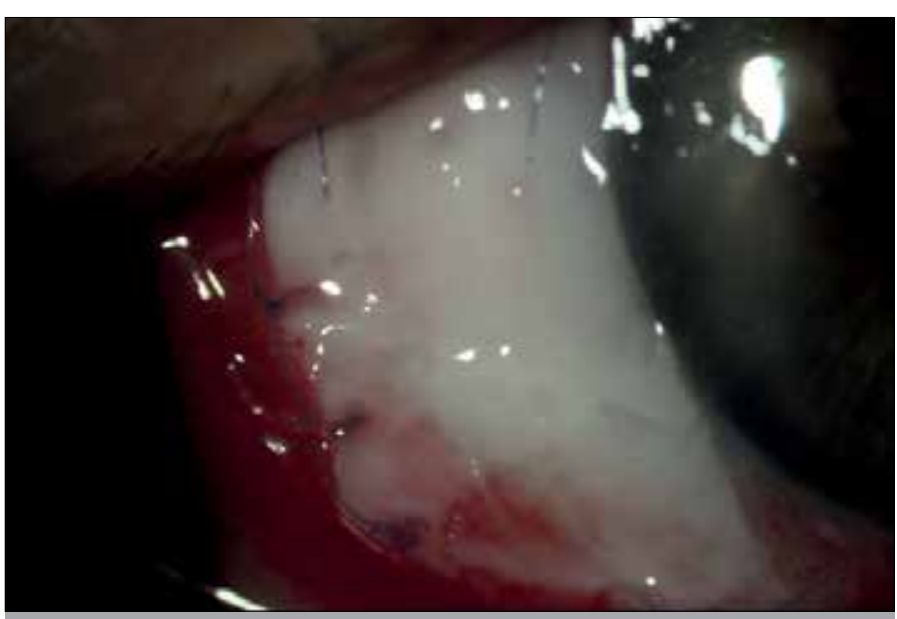

Figure 2. Appearance at postoperative day 1

obtained. Routine ophthalmologic examinations of the patients were performed and the patients were informed about the operation.

All cases operated between December 2016 and May 2017 using T-PRF autograft technique were included in the study. Pterygia exceeding the limbus for $>1 \mathrm{~mm}$ were operated. Patients with recurrent pterygia and other eye diseases were excluded from the study. Cases with positive hepatitis markers and human immunodeficiency virus were also excluded from the study. All cases were handled by the same surgeon.
The patients were controlled at postoperative days 1, 3, 7, and 10, weeks 2 and 4, and then at monthly intervals. At control visits, the cornea and graft were biomicroscopically examined. The presence of recurrence and complications was recorded.

\section{Preparation of T-PRF}

Before preparation of the defect site for operation, blood samples drawn in one attempt using a $20 \mathrm{ml}$ syringe were transferred equally at once into two Grade IV sterile titanium tubes. The tubes were reciprocally placed into the IntraSpin L-PRF centrifuge system and centrifuged at 2,700 rpm for $12 \mathrm{~min}$ at room temperature. PRF clot was removed from the tubes using sterile forceps (Figure 1). It was meticulously separated from the underlying layer of red blood cells. Buffy coat portions of PRFs were removed from serum using a PRF Box, and a homogenous membrane was obtained.

The membranes obtained were stabilized using a disc and were measured using digital calipers. The arithmetic mean of the measured values was calculated to estimate the mean thickness of the graft.

\section{Surgical Technique}

Local anesthesia was applied through a lidocaine injection containing $0.1-0.2 \mathrm{~mL} 2 \%$ epinephrine into the main body of the pterygium. Under an operating microscope, the pterygium was dissected at the level of the limbus using Westcott scissors. The pterygium tissue was separated from the cornea using a crescent knife. Residual tissues on the cornea were meticulously and completely cleansed. For all patients, a diamond-tipped burr was used to smooth out the cornea. The pterygium tissue separated from the cornea was removed using conjunctival scissors together with the underlying Tenon capsule. Bleeding foci (if any) were cauterized using bipolar wet field cautery. The prepared T-PRF was covered over the sclera not exceeding the limbus and was sutured to the conjunctiva with 8/0 polyglactin sutures (Figure 2).

Eyes of all patients were covered using eye bandages after surgery until the corneal epithelium healed. Postoperatively, the patients were given topical tobramycin $(3.00 \mathrm{mg} / \mathrm{mL})$, prednisolone sodium phosphate (1\%), sodium hyaluronate as a lubricant $(0.150$ $\mathrm{g} / 100 \mathrm{~mL}$ ) four times a day, and carbomer (2 mg/1 g) at night before sleeping. Steroids were used for 8 weeks, and other drugs for 1 week. The sutures were removed at postoperative week 2 .

\section{RESULTS}

Twelve eyes of total 12 patients (men, 5 and women, 7) were included in the study. The mean age of the patients was $52.1 \pm 12.6$ (30-75) years. The mean follow-up period of the patients was $2.91 \pm 1.37(1-5)$ months. The follow-up period of total 8 cases exceeded 3 months. Recurrence was observed in total 2 (16.6\%) cases. Recurrences were observed in 1 case at month 4 and in another case with temporal pterygium at month 3 of the follow-up period.

The T-PRF membrane thickness was $0.81 \pm 0.23 \mathrm{~mm}$. The T-PRF membrane was resorbed at a mean period of $8.41 \pm 1.37$ days. In 3 cases, resorption of autograft was observed before completion of conjunctivalization. As a result of early resorption, development of the bare sclera was observed. In other cases, completion of conjunctival epithelization was seen. No complications were observed in any case (Figures 3,4 ). 


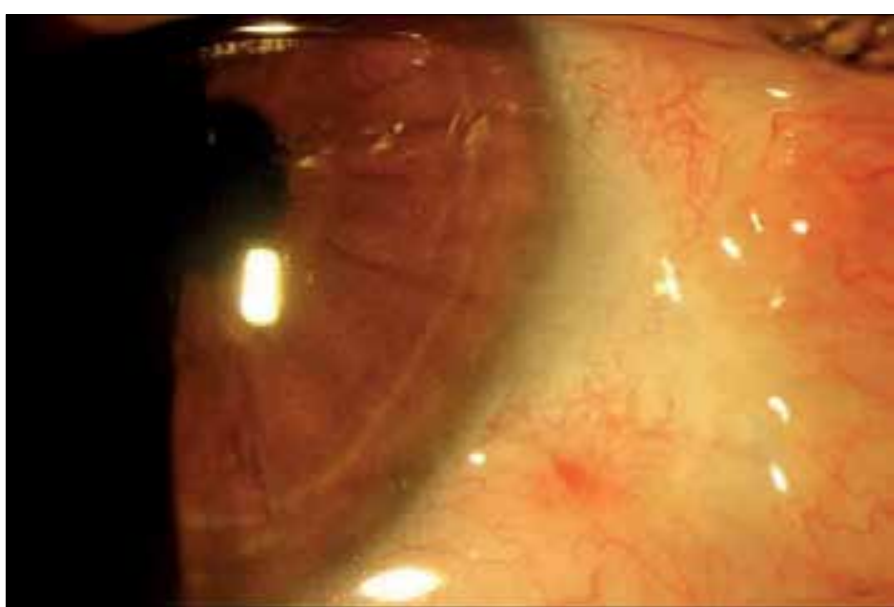

Figure 3. Appearance at postoperative month 1

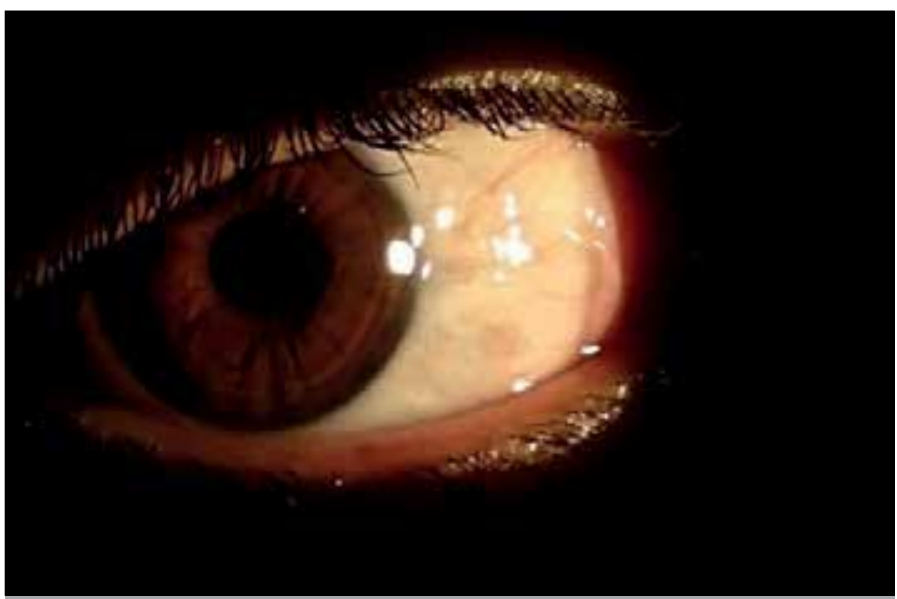

Figure 4. Appearance at postoperative month 2

\section{DISCUSSION}

The main objective of all surgical techniques performed for pterygia was to eliminate the pterygium tissue and to relieve cosmetic and optic problems. Modifying classical techniques and the search for the development of techniques for these methods have prevented the development of recurrence, which is the greatest problem in the treatment of pterygium. Besides, trying to reconstruct tissue that yields the best cosmetic outcomes that cannot be achieved with classical methods has also been a part of this research.

In the literature, recurrence rates of up to $38 \%-88 \%$ have been reported for the bare sclera technique $(19,20)$. A scarce number of studies about simple conjunctival closure technique have been cited in literature, and recurrence rates ranging between $2 \%$ and $69 \%$ have been reported $(21,22)$. However, the safety of the conjunctival flap technique with lower recurrence rates has been indicated in literature (23). Reported recurrence rates ranged between $1 \%$ and $15 \%$ (24-26). In literature, the success rates of conjunctival autograft were reported between $5 \%$ and $30 \%(11,27-36)$; however, for limbal conjunctival autograft technique, recurrence rates varying between $0 \%$ and 15\% have been indicated (37-41).

Recurrence rates ranging from $4 \%$ to $60 \%$ have been reported with the use of an amniotic membrane, which has anti-inflam- matory and antiangiogenic effects $(42,43)$ in pterygium surgery. The use of an amniotic membrane was reported to be more appropriate, particularly in patients with recurrent pterygium who also need glaucoma surgery (44). We believe that the amniotic membrane is an allograft, whereas T-PRF has the advantage of being an autograft. Therefore, T-PRF can replace the amniotic membrane in techniques wherein the use of an amniotic membrane is indicated. Further studies are needed to clarify this issue.

Mitomycin C (MMC) used to decrease recurrence in pterygium surgery also decreases tissue proliferation and fibroblastic activity. When MMC is used, recurrence rates change between $0 \%$ and $40 \%$ (11) The T-PRF membrane we used can be combined with similar additional treatments. In two patients with recurrent pterygium who were not included in our study, we applied T-PRF together with MMC without any subsequent complication, thereby assuring conjunctival epithelization. In cases with recurrent pterygium, MMC-T-PRF combination is being used in a separate study.

Titanium-platelet-rich fibrin (T-PRF) developed by Tunali et al. (16) was first tested in an animal model, and its effectiveness on the healing of connective tissue was investigated. T-PRF used in rabbits persisted at postoperative day 10. It was resorbed at postoperative day 15 and demonstrated a very good regenerative potential with bone calluses and newly formed connective tissue. In our study, early resorption was observed as a disadvantage. The natural characteristics of a teardrop may be the cause of early resorption in addition to the thickness of the membrane. Early resorption causes the formation of bare sclera. The bare sclera increases recurrence rates $(19,20)$. Revisions in surgical technique aiming to prolong resorption time of the autograft are thought to further decrease recurrence rates.

In recent studies, the correlation between angiogenic growth factors such as VEGF, basic fibroblast growth factor, TGF- $\beta$, and PDGF and formation, and recurrence of pterygium has been demonstrated (45-47). Some studies tended to demonstrate that limbal stem cell failure is the main impairment in the pathogenesis of pterygium (11).

L-PRF contains PDGF, TGF- $\beta$, insulin-like growth factor, VEGF, fibroblast-derived growth factor, and epidermal growth factor. Leukocytes trapped in the fibrin matrix secrete some inflammatory and wound healing cytokines (interleukin (IL)-1 $\beta, I L-4, I L-6$, and TNF-a) (48).

Maturation and healing of the soft tissue are realized via angiogenesis, immune control, utilization of the stem cells in circulation, and epithelial closure of the wound site. The effect of the fibrin matrix structure on angiogenesis may be explained by a three-dimensional fibrin gel structure and by the simultaneous activation of the cytokines it contains. Its main angiogenesis is realized by the action of fibroblast growth factor, VEGF, and PDGF, which are soluble factors in the fibrin gel (49).

In an animal study conducted in 2015, Tunalı et al. (50) investigated the effect of T-PRF on bone healing and reported that new bone maturation rate as for new bone formation in the defects induced in rabbit calvaria is at its highest statistically significant level when compared with other groups. Besides, newly formed 
bone retained its original form. This phenomenon suggested that L-PRF may be using tissue memory. Different studies are needed on this subject. We believed that by using T-PRF in pterygium surgery, conjunctivalization might terminate at the limbal border zone.

In conjunctivoplasty, T-PRF autografts provide adequate membranous closure in pterygium surgery. It may offer an advantage, particularly in filtration surgery by leaving the conjunctival space intact. In this surgery that is performed without impairing intact conjunctival tissue, a decrease was observed in the duration of surgery. This technique facilitates harvesting tissues nearby rather than at distant regions.

\section{CONCLUSION}

Our study is still ongoing. The increase in the number of cases will yield more clear-cut outcomes. We wanted to share our preliminary outcomes. Based on our early-phase outcomes, T-PRF can be used in pterygium surgery. Large-scale studies and development of the technique are needed to determine the effectiveness and reliability of this new technique.

Ethics Committee Approval: Ethics committee approval was received for this study from the Ethics Committee of Bezmialem Vakıf University School of Medicine.

Informed Consent: Written patient consent was obtained from patients participating in this study.

Peer-review: Externally peer-reviewed.

Author Contributions: Concept - F.N.; Design - B.Ç.T.; Supervision H.Ö.; Resources - M.T.; Materials - F.N.; Data Collection and/or Processing - F.N.; Analysis and/or Interpretation - F.N.; Literature Search - F.N.; Writing Manuscript - F.N.; Critical Review - H.Ö

Conflict of Interest: The authors have no conflicts of interest to declare.

Financial Disclosure: The authors declared that this study has received no financial support.

\section{REFERENCES}

1. Verlee DL. Ophthalmic survey in the Solomon Islands. Am j Ophthalmol 1986; 66: 304. [CrossRef]

2. Saw SM, Tan D. Pterygium: prevalance, demography and risk factors. Ophthalmic Epidemiol 1999; 6: 219-28. [CrossRef]

3. Rojas Jr, Malaga H. Pterygium in Lima, Peru. Ann Ophthalmol 1986; 18: 147-9

4. Forsius H, Maertens K, Fellman J. Changes of the eye caused by the climate in Rwanda, Africa. Ophthalmic Epidemiol 1995; 2: 107-13. [CrossRef]

5. Hill JC, Maske R. Pathogenesis of pterygium. Eye 1989; 3: 218-26. [CrossRef]

6. Mohammed I. Treatment of pterygium. Ann Afr Med 2011; 10: 197203. [CrossRef]

7. Di Girolamo N, Chui J, Coroneo MT, Wakefield D. Pathogenesis of pterygia: role of cytokines, growth factors, and matrix metalloproteinases. Prog Retin Eye Res 2004; 23: 195-228. [CrossRef]

8. Tekelioglu Y, Turk A, Avunduk AM, Yulug E. Flow cytometrical analysis of adhesion molecules, T-lymphocyte subpopulations and inflammatory markers in pterygium. Ophthalmologica 2006; 220: 372-8. [CrossRef]

9. Detorakis ET, Spandidos DA. Pathogenetic mechanisms and treatment options for ophtalmic pterjum: trends and perspectives. Int J Mol Med 2009; 23: 439-47. [CrossRef]
10. Nuhoğlu F, Özdemir FE, Sarıcı K, Abul D. New Limboconjunctival Flap Technique in the Surgical Treatment of Primary Pterygium: A Preliminary Report. JAREM 2015: 5; 17-21. [CrossRef]

11. Hacıoğlu D, Erdöl H. Developments and current approaches in the treatment of pterygium. Int Ophthalmol 2017; 37: 1073-8. [CrossRef]

12. Choukroun J, Adda F, Schoeffler C, Vervelle A. An opportunity in perioimplantology: the PRF. Implantodontie 2001; 42: 55-62.

13. Dohan DM, Choukroun J, Diss A, Dohan SL, Dohan AJ, Mouhyi J, et al. Platelet-rich fibrin (PRF): a second-generation platelet concentrate. Part I: technological concepts and evolution. Oral Surg Oral Med Oral Pathol Oral Radiol Endod 2006; 101: 37-44. [CrossRef]

14. Dohan DM, Choukroun J, Diss A, Dohan SL, Dohan AJ, Mouhyi J, et al. Platelet-rich fibrin (PRF): a second-generation platelet concentrate. Part II: platelet-related biologic features. Oral Surg Oral Med Oral Pathol Oral Radiol Endod 2006; 101: 45-50. [CrossRef]

15. O'Connell SM. Safety issues associated with platelet-rich fibrin method. Oral Surg Oral Med Oral Pathol Oral Radiol Endod 2007; 103: 587-93. [CrossRef]

16. Tunali M, Ozdemir H, Kucukodaci Z, Akman S, Firatli E. In vivo evaluation of titanium-prepared platelet-rich fibrin (T-PRF): a new platelet concentrate. Br J Oral Maxillofac Surg 2013; 51: 438-43. [CrossRef]

17. Ustaoğlu G, Ercan E, Tunali M. The role of titanium-prepared platelet-rich fibrin in palatal mucosal wound healing and histoconduction. Acta Odontol Scand 2016; 74: 558-64. [CrossRef]

18. Can ME, Çakmak HB, Dereli Can G, Ünverdi H, Toklu Y, Hücemenoğlu S. A Novel Technique for Conjunctivoplasty in a Rabbit Model: Platelet-Rich Fibrin Membrane Grafting. J Ophthalmol 2016; 1965720. [CrossRef]

19. Alpay A, Uğurbas $S$, Erdoğan B. Comparing techniques for pterygıum. Clin Ophthalmol 2009; 3: 69-74.

20. Ozer A, Yildirim N, Erol N, Yurdakul S. Long-term results of bare sclera, limbal-conjunctival autograft and amniotic membrane graft techniques in primary pterygium excisions. Ophthalmologica 2009; 223: 269-73. [CrossRef]

21. Anduze AL. Merest sclera technique for primary pterygium surgery Ophthalmic Surg 1989; 20: 892-4.

22. Riordan-Eva P, Kielhorn I, Ficker LA, Steele AD, Kirkness CM. Conjunctival autografting in the surgical management of pterygium. Eye 1993; 7: 634-8. [CrossRef]

23. Kenyon KR, Wagoner MD, Hettinger ME. Conjunctival autograft transplantation for advanced and recurrent pterygium. Ophthalmology 1985; 92: 1461-70. [CrossRef]

24. Lei G. Surgery for pterygium using a conjunctival pedunculated flap slide. Br J Ophthalmol 1996; 80: 33-4. [CrossRef]

25. Akura J, Kaneda S, Matsuura K, Setogawa A, Takeda K, Honda S. Measures for preventing recurrence after pterygium surgery. Cornea 2001; 20: 703-7. [CrossRef]

26. Hirst LW. The treatment of pterygium. Surv Ophthalmol 2003; 48: 145-80. [CrossRef]

27. Lewallen S. A randomized trial of conjunctival autografting for pterygium in the tropics. Ophthalmology 1989; 96: 1612-4. [CrossRef]

28. Allan BD, Short P, Crakford GJ, Barret GD, Constable IJ. Pterygium excision with conjunctival autografting: an effective and safe technique. Br J Ophthalmol 1993; 77: 698-703. [CrossRef]

29. Ti SE, Chee SP, Dear KB et al. Analysis of variation in success rates in conjunctival autografting for primary and recurrent pterygium. $\mathrm{Br} \mathrm{J}$ Ophthalmol 2000; 84: 385-9. [CrossRef]

30. Kmiha N, Kamoun B, Trigui A, Jelliti B, Fourati M, Chaabouni M. Effectiveness of conjunctival Int Ophthalmol 123 autograft transplantation in pterygium surgery. J Fr Ophtalmol 2001; 24: 729-32.

31. Seid A, Bejiga A. Free conjunctival autograft in the management of advanced primary and recurrent pterygia. East Afr Med J 2000; 77: 588-91. 
32. Chaidaroon W, Wattananikorn S. Conjunctival autograft transplantation for primary pterygium. J Med Assoc Thai 2003; 86: 111-5.

33. Huerva V, March A, Martinez-Alonso M, Muniesa MJ, Sanchez C. Pterygium surgery by means of conjunctival autograft: long term followup. Arq Bras Oftalmol 2012; 75: 251-5. [CrossRef]

34. Varssano D, Shalev H, Lazar M, Fischer N. Pterygium excision with conjunctival autograft: true survival rate statistics. Cornea 2013; 32: 1243-50. [CrossRef]

35. Kocamis $\mathrm{O}$, Bilgec $\mathrm{M}$. Evaluation of the recurrence rate for pterygium treated with conjunctival autograft. Graefes Arch Clin Exp Ophthalmol 2014; 252: 817-20. [CrossRef]

36. Koranyi G, Seregard S, Kopp ED. The cut-and-paste method for primary pterygium surgery: long-term followup. Acta Ophthalmol Scand 2005; 83: 298-301. [CrossRef]

37. Oguz H. Inferior limbal conjunctival autograft transplantation for recurrent pterygium. Indian J Ophthalmol 2003; 51: 108-9.

38. Al-Fayez MF. Limbal versus conjunctival autograft transplantation for advanced and recurrent pterygium. Ophthalmology 2002; 109: 1752-5. [CrossRef]

39. Malik KP, Goel R, Gutpa A, Gupta SK, Kamal S, Mallik VK, et al. Efficacy of sutureless and glue free limbal conjunctival autograft for primary pterygium surgery. Nepal J Ophthalmol 2012; 4: 230-5. [CrossRef]

40. Al Fayez MF. Limbal-conjunctival versus conjunctival autograft transplant for recurrent pterygia: a prospective randomized controlled trial. JAMA Ophthalmol 2013; 131: 11-6. [CrossRef]

41. Masters JS, Harris DJ Jr. Low recurrence rate of pterygium after excision with conjunctival limbal autograft: a retrospective study with long-term follow-up. Cornea 2015; 34: 1569-72. [CrossRef]

42. Shimazaki J, Shinozaki N, Tsubota K. Transplantation of amniotic membrane and limbal autograft for patients with recurrent pterygium associated with symblepharon. $\mathrm{Br} \mathrm{J}$ Ophthalmol 1998; 82: 235-40. [CrossRef]
43. Shimazaki J, Kosaka K, Shimmura S, Tsubota K. Amniotic membrane transplantation with conjunctival autograft for recurrent pterygium. Ophthalmology 2003; 110: 119-24. [CrossRef]

44. Luanratanakorn P, Ratanapakorn T, Suwan-Apichon O, Chuck RS. Randomised controlled study of conjunctival autograft versus amniotic membrane graft in pterygium excision. Br J Ophthalmol 2006: 90: 1476-80. [CrossRef]

45. Di Girolamo N, Kumar RK, Coroneo MT, Wakefield D. UVB-mediated induction of interleukin- 6 and -8 in pterygia and cultured human pterygium epithelial cells. Invest Ophthalmol Vis Sci 2002; 43: 3430-7.

46. Nolan TM, DiGirolamo N, Sachdev NH, Hampartzoumian T, Coroneo MT, Wakefield $D$. The role of ultraviolet irradiation and heparinbinding epidermal growth factor-like growth factor in the pathogenesis of pterygium. Am J Pathol 2003; 162: 567-74. [CrossRef]

47. Di Girolamo N, Wakefield D, Coroneo MT. UVB-mediated induction of cytokines and growth factors in pterygium epithelial cells involves cell surface receptors and intracellular signaling. Invest Ophthalmol Vis Sci 2006; 47: 2430-7. [CrossRef]

48. Dohan DM, Choukroun J, Diss A, Dohan SL, Dohan AJ, Mouhyi J, et al. Platelet-rich fibrin (PRF): a second-generation platelet concentrate. Part III: leucocyte activation: a new feature for platelet concentrates? Oral Surg Oral Med Oral Pathol Oral Radiol Endod 2006; 101 : 51-5. [CrossRef]

49. Edel A. Clinical evaluation of free connective tissue grafts used to increase the width of keratinised gingiva. J Clin Periodontol 1974; 1 : 185-96. [CrossRef]

50. Tunalı M, Özdemir H, Küçükodacı Z, Ezirganlı S, Barış E, Akman S, et al. A novel platelet concentrate for guided bone regeneration: Titanium Prepared Platelet-Rich Fibrin (T-PRF). Gulhane Tip Derg 2015; 57: 102-6. [CrossRef] 